Apidologie, 1982, 13 (3), 297-306

\title{
A COMPARATIVE ANALYSIS OF SHAKING SOLUTIONS FOR THE DETECTION OF VARROA JACOBSONI ON ADULT HONEYBEES (1)
}

\author{
D. DE JONG (2-3), D. DE ANDREA ROMA (3) and L. S. GONÇALVES (4)
}

\section{SUMMARY}

Various liquids could be used for the detection of Varroa jacobsoni on honey bees using the shaking method. Mechanical shaking for 30 minutes in a rotary shaker disloged all but 3 mites in 27 separate examinations.

The ectoparasitic honey bee mite Varroa jacobsoni, first described by OudEMANS (1904) from the Asian honey bee Apis cerana in Java, is distributed throughout Asia, wherever A.Cerana occurs (DE JONG and MORSE 1979). Since the 1950's, and probably earlier, beekeepers have moved colonies of European bees, $A$. mellifera, into Asia (CRANE 1978) and in some cases colonies of $A$. cerana (infested with Varroa) from Asia into Europe (LANGHE and NATSKII 1976, RuTtNer and RitTer, 1980) and, as a result of contact between the two bee species, $V$.jacobsoni has moved to A. mellifera as a new host (CRANE 1978, MORSE, 1978). Although A. cerana is not seriously affected by the mites, colonies of $A$. mellifera are severely compromised (Alpatov 1977). Within the last twenty years V.jacobsoni has extended its range from Asia to Eastern and Western Europe. Northern Africa and much of South America (Crane 1978, 1979).

The mites cause damage to adult and developing honey bees as they feed on the bee's hemolymph. In colonies with low populations, the developing bees may lose 5 to $25 \%$ of their weight; occasionally there is damage to wings or other appendages. However, the signs are easily missed as only a small percentage of emerging bees are obviously deformed even when over $50 \%$ of the brood cells are infested (DE JONG et

(1) This investigation was supported by N.S.F. Grant No. D.A.R. - 7920922 to R. A. MorsE and grants from the Foundation for the Support of Research in the State of São Paulo (F.A.P.E.S.P.) and the Brazilian Research Council (C.N.P.Q.) to L. S. GonÇALVES.

(2) Department of Entomology, Cornell University, Ithaca, NY 14853, U.S.A.

(3) Depto. de Genetica, Faculdade de Medicina, U.S.P., 14.100 Ribeirão Preto, SP Brazil.

(4) Faculdade de Filosophia, Ciências e Letras, U.S.P., 14.100 Ribeirão Preto, SP Brazil. 
al., submitted for publication). Most of the damaged bees are immediately removed from the colony by house-cleaning bees (DE JONG, unpublished data). When infestations have increased to the point that they are noticeable, the mite populations are already quite high (DE JONG and GoNÇALVEs 1981). During the three to six years necessary for a new infestation to reach this point, the mites are widely dispersed by drifting bees, swarms and the movement of colonies by man (PHADKE et al., 1966, SMIRNOv 1978). It is therefore desirable to locate new foci of infestation early so that the mites can be controlled or eliminated.

There are two principal ways of examining bee colonies for the presence of $V$. jacobsoni. One method is to uncap brood cells and remove the larvae or pupae for examination. Since the mites have a preference for drone brood (RITTER and RUTTNER 1980), examining drone cells is usually more productive. A second method involves an examination of the adult bees by shaking them in a solution which will dislodge the mites. Large numbers of bees can be sampled in a short time by this method, facilitating the detection of low-level infestations and providing a means for estimation of mite populations.

Varroa jacobsoni that are attached superficially to the bee are easy to remove by shaking bees in a liquid phase. However, mites that are attached to the intersegmental membranes of the abdominal sternites or tergites are difficult to see and to remove even if the bees are dead. Several types of solutions have been used for shaking bees to detect V.jacobsoni. These include hot water (GROBOV 1977), detergent solutions (StOlbov and VASIKov 1976), hexane or gasoline (RITTER and RUTTNER 1980) and $96 \%$ ethanol (DE Jong and GonçALves 1981). Gasoline is reportedly nearly $100 \%$ effective for separating mites from adult bees (RITTER and RUTTNER 1980); however, it is dangerous to use as the fumes are toxic and highly flammable. In Brazil ethanol was found equally effective (GoNÇALVEs et al., 1980), but in most other countries it may be costly and not readily available.

Since the shaking technique is used frequently for the detection of V. jacobsoni, we decided to test the various products to compare their efficiency for extracting mites. Solutions were selected according to availability and facility of use. We tested each solution with and without the use of a laboratory shaker. Dried samples were also tested to determine the suitability of winter-killed bees or dried samples sent to a central laboratory for diagnosis.

\section{MATERIALS AND METHOD}

A plastic shaking container developed in Brazil (DE JONG and GonçALves 1981) was used for all of the experiments. It consisted of a 1-1 plastic alcohol bottle that had a constriction in the middle. The middle third section of the construction was cut out and the portions reassembled. A round piece of wire screening with openings $3 \mathrm{~mm}$ square (these should be larger than 1.9 , but smaller than $4.5 \mathrm{~mm}$ ) was cut slightly larger than the inside diameter of the bottle, then the screen was fitted into the upper end of the 
bottle from the inside. With the bottle cap in place the inverted bottle assembly retained the bees above the screen while the mites dropped down to the neck of the bottle (Fig. 1). Where such a container is not

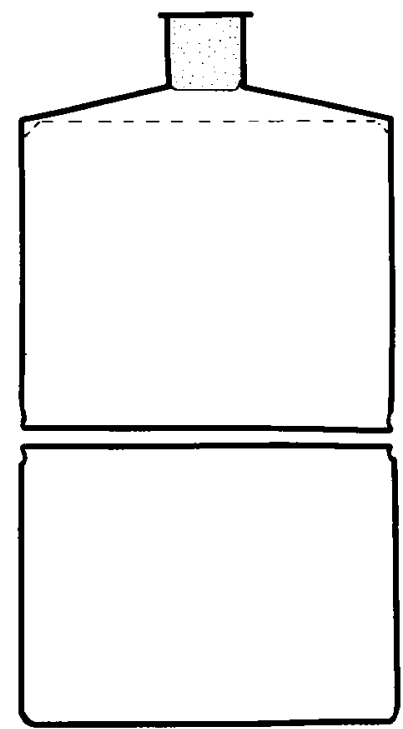

Fig. 1. - Diagramatic sketch of container for shaking bees.

The bottom (shown here separated from the top)

contains a screen (dashed line) through which the mites fall.

available, a shaking container can be made by cutting the bottom off any plastic bottle and using a piece of flexible plastic wrap secured with a piece of elastic as a cover for the bottom. Several small holes about $0.5 \mathrm{~mm}$ diameter should be made in the top of the shaker or in the plastic wrap to allow for the release of air pressure caused by the evaporation of fluids during the shaking process. Adult bee samples were collected by brushing them from brood combs into a beaker or other wide-mouth container with $150 \mathrm{ml}$ of shaking solution. The bees and solution were then poured into the shaking container (with cap in place) and enough extra solution added to cover all of the bees. Each bottle was agitated by hand with the cap down and moved in a circular motion for one minute. The solution was then poured into a bowl lined with a white small mesh cloth. The cloth was then lifted from the bowl and the mites on the cloth counted. The bottle was then recapped and refilled with the same solution and subjected to 30 minutes of circular agitation in a laboratory shaker. Additional mites separated by the second shaking were counted as before. As a final check all of the bees were examined individually for remaining mites.

In a separate test, two samples of live bees were placed into empty jars and killed by freezing overnight. One sample was dried in the sun for $24-\mathrm{hr}$. at $24-27^{\circ} \mathrm{C}$ and the other oven-dried at $60^{\circ} \mathrm{C}$ for 2-hr. The bees were then subjected to the shaking procedure using $96 \%$ ethanol.

\section{RESULTS AND DISCUSSION}

The mean number of mites per samples was .156 per bee, with a range of .0237 to 583 (Table 1). Hand-shaking for one minute was reasonably effective, but for all solutions tested, mechanical shaking for 30 minutes effectively removed $100 \%$ of the mites. Only rarely were mites encountered on bees after they had been through the mechanical shaking. 
Several of the solutions were inconvenient to use. Many of the bees in water $25^{\circ} \mathrm{C}\left(77^{\circ} \mathrm{F}\right)$ were able to crawl out of the container. This was less of a problem with water at $40^{\circ} \mathrm{C}\left(104^{\circ} \mathrm{F}\right)$. The hot water, $60^{\circ} \mathrm{C}\left(140^{\circ} \mathrm{F}\right)$, and $100^{\circ} \mathrm{C}\left(212^{\circ} \mathrm{F}\right)$ was difficult to handle without an insulated container. Bees quickly succumbed in the

TABL. 1. - Number of mites detected with shaking solutions.

\begin{tabular}{|c|c|c|c|c|}
\hline \multirow[b]{2}{*}{ Solution } & \multicolumn{3}{|c|}{ No. mites } & \multirow[b]{2}{*}{ No. bees } \\
\hline & $\begin{array}{l}\text { Hand-shaking } \\
\text { one minute }\end{array}$ & $\begin{array}{l}\text { Mechanical shaker } \\
30 \text { minutes }\end{array}$ & $\begin{array}{l}\text { Mites remaining } \\
\text { on bees }\end{array}$ & \\
\hline $\begin{array}{c}\text { Ethanol } \\
15 \% * \\
25 \% \\
25 \% \\
25 \% \\
50 \% \\
70 \% \\
96 \% \\
96 \% \\
96 \%\end{array}$ & $\begin{array}{r}18 \\
32 \\
56 \\
27 \\
153 \\
62 \\
26 \\
47 \\
131\end{array}$ & $\begin{array}{l}5 \\
2 \\
4 \\
1 \\
2 \\
5 \\
1 \\
0 \\
5\end{array}$ & $\begin{array}{l}0 \\
0 \\
0 \\
0 \\
1 \\
0 \\
0 \\
0 \\
0\end{array}$ & $\begin{array}{l}317 \\
246 \\
279 \\
410 \\
368 \\
413 \\
224 \\
278 \\
277\end{array}$ \\
\hline $\begin{array}{c}\text { Isopropyl } \\
25 \% \\
25 \% \\
50 \% \\
50 \%\end{array}$ & $\begin{array}{l}43 \\
15 \\
38 \\
33\end{array}$ & $\begin{array}{l}2 \\
4 \\
4 \\
1\end{array}$ & $\begin{array}{l}0 \\
0 \\
1 \\
0\end{array}$ & $\begin{array}{l}258 \\
295 \\
294 \\
391\end{array}$ \\
\hline $\begin{array}{c}\text { Water* } \\
25^{\circ} \mathrm{C} \\
40^{\circ} \mathrm{C} \\
40^{\circ} \mathrm{C} \\
40^{\circ} \mathrm{C} \\
60^{\circ} \mathrm{C} \\
100^{\circ} \mathrm{C} \\
100^{\circ} \mathrm{C}\end{array}$ & $\begin{array}{r}11 \\
5 \\
8 \\
66 \\
11 \\
10 \\
13\end{array}$ & $\begin{array}{r}6 \\
2 \\
14 \\
13 \\
2 \\
2 \\
4\end{array}$ & $\begin{array}{l}1 \\
0 \\
0 \\
0 \\
0 \\
0 \\
0\end{array}$ & $\begin{array}{l}202 \\
295 \\
411 \\
203 \\
267 \\
420 \\
389\end{array}$ \\
\hline $\begin{array}{c}\text { Tw'een } 80^{*} \\
1 \% \\
A D E C I D-C\end{array}$ & $? 7$ & 6 & 0 & 407 \\
\hline $\begin{array}{c}1 \% \\
O D D \\
1 \% \\
1 \%\end{array}$ & $\begin{array}{r}104 \\
\\
20 \\
142\end{array}$ & $\begin{array}{l}4 \\
0 \\
6\end{array}$ & $\begin{array}{l}0 \\
0 \\
0\end{array}$ & $\begin{array}{l}281 \\
\\
357 \\
254\end{array}$ \\
\hline $\begin{array}{l}S D S \\
.4 \% \\
.4 \% \\
.4 \%\end{array}$ & $\begin{array}{l}23 \\
21 \\
97\end{array}$ & $\begin{array}{l}0 \\
3 \\
6\end{array}$ & $\begin{array}{l}0 \\
0 \\
0\end{array}$ & $\begin{array}{l}430 \\
458 \\
230\end{array}$ \\
\hline
\end{tabular}

* Percentage of total mites detected by hand-shaking alone significantly less (P .05) than that obtained with $96 \%$ ethanol (contingency table analysis with correction for continuity, Snedecor and Cochran, 1980). Data were lumped for each kind of solution, except for ethanol solutions which were separated according to concentration.

Aqueous detergent solutions.

Tween 80 , Merck.

ADECID-C $40 \%$ Polyethlene-nonyl phenyl ether, $60 \%$ inert ingredients. Mitsui Ihara, S.A.

ODD Orinex S/A, São Paulo, Brazil. This is a commonly used liquid dishwashing detergent manufactured and distributed in Brazil; formula not revealed.

SDS Sodium dodecyl sulfate. Electrophoresis purity reagent. Bio-Rad laboratories. Richmond, California. 
detergent solutions as well as in the ethanol and isopropyl alcohol. The foam in the detergent solutions sometimes made it difficult to count mites, though rinsing the filter cloth with additional water usually eliminated this problem.

The results from the various solutions were compared to those obtained with $96 \%$ ethanol to determine if they were equally effective in extracting the mites using only hand-shaking. Water, Tween- 80 , and $15 \%$ ethanol were significantly less efficient. However, there was no significant advantage to using $96 \%$ ethanol over the remaining alcohol solutions.

The shaking procedure using dried bee samples proved unreliable. Over $10 \%$ of the mites remained attached to the dried bees even after 30 minutes of mechanical shaking in $96 \%$ ethanol (Table 2). In contrast, $100 \%$ of the mites were dislodged from freshly killed bees by the same treatment.

TABL. 2. - Number of mites detected in air dried bee samples shaken in $96 \%$ ethanol.

\begin{tabular}{l|c|c|c|c|c}
\hline \hline & $\begin{array}{c}\text { found in container } \\
\text { after freezing }\end{array}$ & $\begin{array}{c}\text { fell off } \\
\text { during drying }\end{array}$ & $\begin{array}{c}\text { hand shaking } \\
\text { one minute }\end{array}$ & $\begin{array}{c}\text { mechanical shaker } \\
\text { thirty minutes }\end{array}$ & $\begin{array}{c}\text { remaining } \\
\text { mites }\end{array}$ \\
\hline $\begin{array}{l}\text { (868) bees oven dried } \\
\text { at } 60^{\circ} \mathrm{C} \text { for two } \\
\text { hours } \ldots \ldots \ldots \ldots\end{array}$ & 2 & 4 & 10 & 9 & 5 \\
$\begin{array}{l}\text { (848) bees sun-dried } \\
\text { for three hours then } \\
24 \text { hours at } 24-27^{\circ} \mathrm{C}\end{array}$ & 2 & 8 & 5 & 3 & 7 \\
\hline \hline
\end{tabular}

\section{CONCLUSIONS}

Shaking bees in various solutions is an efficient means of detecting the presence of $V$. jacobsoni in samples of freshly killed adult honey bees. Twenty-five percent solutions of ethanol or isopropyl alcohol were effective, convenient to use, and reasonable in cost. Hand-shaking for one minute removed $79-96 \%$ (average $92 \%$ ) of the mites when $25 \%$ alcoholic solutions were used. Mechanical shaking on a rotary shaker for 30 minutes using $25 \%$ alcoholic solutions removed $100 \%$ of the mites. The difference in efficiency of mite removal between hand-shaking and mechanical shaking was statistically significant.

Dried adult bee samples, which are more easily shipped to a central laboratory, can be diagnosed with a shaking solution, although the method is not as reliable as when freshly killed bees are used. 


\title{
RÉSUMÉ \\ ÉTUDE COMPARATIVE DE LA DÉTECTION DE VARROA JACOBSONI PAR AGITATION DES ABEILLES DANS DES SOLUTIONS
}

Secouer des abeilles dans diverses solutions est un moyen efficace pour détecter la présence de Varroa jacobsoni dans des échantillons d'abeilles adultes fraichement tuées. Des solutions d'éthanol ou d'alcool isopropylique à $25 \%$ sont efficaces, faciles d'utilisation et d'un coût raisonnable. L'agitation manuelle dans des solutions alcooliques à $25 \%$ pendant une minute a éliminé $79-96 \%$ (en moyenne $92 \%$ ) des acariens. L'agitation mécanique sur un agitateur centrifuge pendant 30 minutes dans des solutions alcooliques à $25 \%$ a éliminé la totalité ( $100 \%$ ) des acariens. La nature de la solution, qu'il s'agisse de solutions alcooliques, de détergents ou d'eau chaude, ne semble pas être décisive dans le cas de l'agitation mécanique. La différence d'efficacité entre l'agitation manuelle et l'agitation mécanique est statistiquement significative.

On peut établir un diagnostic sur des échantillons d'abeilles adultes séchées, plus faciles à expédier à un laboratoire central, par agitation dans une solution, bien que la méthode ne soit pas aussi fiable qu'avec des abeilles fraichement tuées.

Le récipient utilisé pour le test d'agitation est une bouteille d'alcool en plastique d'un litre, possédant un rétrécissement dans son milieu. Le tiers médiant de la bouteille avec le rétrécissement a été supprimé et les deux portions rassemblées après avoir ajusté de l'intérieur un morceau circulaire de grillage métallique, ayant une maille de $3 \mathrm{~mm}^{2}$ ( $>1,9$ et $<4,5 \mathrm{~mm}$ ), dans la partie supérieure de la bouteille.

\section{ZUSAMMENFASSUNG}

\author{
VERGLEICHENDE PRÜFUNG VON SCHÜTTELLÖSUNGEN \\ FÜR DAS AUFFINDEN VON VARROA JACOBSONI AN ADULTEN BIENEN
}

Das Schütteln der Bienen in verschiedenen Lösungen ist ein wirkungsvolles Mittel, um das Vorhandensein von Varroa jacobsoni in Proben von frisch getöteten adulten Honigbienen zu entdecken. $25 \%$ ige Lösungen von Äthanol oder Isopropylalkohol zeigten ein gutes Ergebnis, waren angenehm im Gebrauch und günstig in den Kosten. Schütteln von Hand durch 1 Minute entfernte $79-96 \%$ (im Mittel $92 \%$ ) der Milben, wenn $25 \%$ ige Alkohollösungen benutzt wurden. Mechanisches Schütteln für 30 Minuten in einem rotierenden Schüttler entfernten in einer $25 \%$ igen Alkohollösung $100 \%$ der Milben. Die Art der Schüttellösung schien nicht entscheidend zu sein - gleichgültig, ob es sich um alkoholische Lösungen, um Detergentien oder um heisses Wasser handelte, sofern ein mechanischer Schüttler benutzt wurde. Der Unterschied im Wirkungsgrad der Milbenentfernung zwischen Schütteln von Hand oder mechanischem Schütteln war statistisch signifikant.

Auch Proben von getrockneten adulten Bienen, deren Versand zu einem Zentrallaboratorium einfacher ist, können mit einer Schüttellösung diagnostiziert werden, aber die Methode ist nicht so verlässlich wie bei Verwendung von frisch getöteten Bienen.

Als Schüttelgefäss wurde in diesem Versuch eine 1-Liter Plastik-Alkoholflasche mit einer Einnehmung in der Mitte benutzt. Das mittlere Drittel der Flasche mit der Einnehmung wurde herausgeschnitten, die Teile wurden nachher wieder zusammengesetzt. Ein rundes Stück Drahtgitter mit Maschen von $3 \mathrm{~mm}^{2}$ $(>1,9<4,5 \mathrm{~mm}$ ) wurde von innen in das obere Ende der Flasche eingepasst (Abb. 1).

\section{BIBLIOGRAPHY}

Alpatov V. V., 1977. - (Varroa jacobsoni in other countries). In Alpatov, V. V. et al., editors, 1977. (Varroa infestations of honeybees). Izdatel'stvo Nauka : 9-12. I.B.R.A. translation, No. 1552.

Crane E., 1968. - Mites infesting honeybees in Asia. Bee World, 49 : 113-114. 
Crane E., 1979. - Fresh news on the Varroa mite. Bee World, $60: 8$.

De Jong D., Gonçalves L.S., 1981. - The Varroa problem in Brazil, American Bee Journal, 121 : 186 189.

DE Jong D., Morse R. A., 1979. - Annotated bibliography on Varroa jacobsoni, Tropilaelaps clareae, Euvarroa sinhai. International Bee Research Association Bibliography, No. 15, $36 \mathrm{p}$.

Gonçalves L. S., MorSe R. A., Stort A. C., 1979. - Incidence of the mite Varroa jacobsoni in the colonies of Africanized bees in the state of São Paulo. Apimondia (Athens), 27 : 374-378.

Grobov O.F., 1977. - Varroasis in bees. In : Varroasis, a honeybee Disease. pp. 46-90. Bucharest : Apimondia.

Langhe A. B., Natski K. V., 1976. - (The mite Varroa and the methods of controlling it.). Pchelovodstvo (3) : 16-20.

MoRse R. A., 1978. - Arachnids : Acarina (mites and ticks). In Honeybee Pests, Predators, and Diseases. ed. R.A. Morse, pp. 197-209. Ithaca, New York : Cornell University Press.

Phadke K. G., Bisht D. S., SinHa R.B.P., 1966. - Occurrence of the mite Varroa jacobsoni Oudemans in the brood cells of the honeybee, Apis indica $F$. Indian Journal of Entomology, $28: 411-412$.

RitTer W., RUTTNER F., 1980. - Diagnoseverfahren (Varroa). Allg. dtsch. Imkerztg. (5) : 134-138.

RUtTNER F., RitTer W., 1980. - Das Eindringen von Varroa jacobsoni nach Europa im Rückblick, Allgemeine Deutsche Imkerzeitung, (5) : 130-133.

SMIRNOv A. M., 1978. - Research results obtained in U.S.S.R. concerning aetiology, pathogenesis, epizootiology, diagnosis and control of Varroa disease in bees. Apiacta, $13: 149-162$.

SNEdeCor G. W., Cochran W. G., 1980. - Statistical Methods. Seventh Edition. Iowa State University Press. Ames, Iowa, U.S.A. 